\title{
Kapa magazine, 1990 - 1993: A survey on postmodern graphic design and appropriation
}

abstract The essay aims to explore the graphic references of postmodern Portuguese magazine Kapa, published from 1990 to 1993. Designed by João Botelho and Luís Miguel Castro, the magazine was strongly influenced by the art direction of Alexey Brodovitch in Harper's Bazaar (1934-1958), who played an important role in introducing the European Modernist aesthetics in American editorial background. The historical context of Kapa is exposed as well its editorial and graphic features. The "retro" expression of the magazine draws the importance of relating graphic references from Russian Constructivism and European Modernism to the American mainstream magazines of the 30 to 50 s. The affinity between visual language and ideology is an important clue to understand the use of past references in postmodern design. This appropriation and the reasons beyond it are the main questions of this essay.

keywords graphic design, postmodernism, appropriation, Ideology

\section{Introduction}

This paper is part of a doctoral research about the Portuguese magazine Kapa, published from 1990 to 1993 as its contribution to postmodern graphic design. Going beyond the Portuguese context, this survey intends to place Kapa in the wider background of graphic design history.

Kapa's graphic style is mostly linked to the "retro" expression of postmodern graphic design, being strongly influenced by Alexey Brodovitch's art direction of Harper's Bazaar (1934-1958). Brodovitch was educated as a designer within the Modernist and Constructivist movements in Europe, moving later to USA, as many other artists, designers and architects between World Wars.

The question this paper intends to explore is the use of such strong past references in a gos magazine. It is proposed to take a chronological leap backwards in design history, from Postmodern design appropriation of historical legacies to the expression of Modernist graphic design in Europe and Russia.

During the second half of the 8os Portugal was living an economical growth, due to its integration in European Community in 1986, and there was an increasing private investment in new mass media communications. Thus, a lot of magazines and newspapers were published, convoking plenty of editorial agents to a free public discourse. After 48 years of a conservative dictatorship lead by António Salazar, which ended with the 1974 Revolution, left wing parties and compounds controlled most of the editorial press, using 
theme 2

memory

Figure 1.

Luís Miguel Castro. Cover of Kapa n० 1 (1990) strand 1

design histories: tradition, transgression and transformations

it as a doctrinal medium to spread Socialist ideas. However, their graphic production was inconsistent, fragile and undefined in terms of graphic references.

Kapa magazine was a direct descendant of the weekly newspaper $O$ Independente, published in 1988. In his first editorial the newspaper director Miguel Esteves Cardoso quoted Arthur Miller: "A good newspaper is a nation talking to itself" and O Independente wants to take part of this conversation" (Cardoso 1988: 2). The newspaper was mainly attached to a conservative ideology, proclaiming itself as liberal. Its main concern was a patriotic argument: the integrity of Portuguese values and culture against any kind of power abuse, in opposition to the ruling government, a center left wing party headed by Cavaco Silva. The newspaper was responsible for reporting political scandals, which led to Miguel Esteves Cardoso resignation in 1990.

The newspaper was designed by Jorge Colombo. Inspired by the French newspaper La Libération, the result was an elegant black and white layout, only coloured with blue on the first page, displaying well-designed typography, well-proportioned grid and a sober composition. The art direction was mostly supported by photography, with the collaboration of a new generation of photographers.

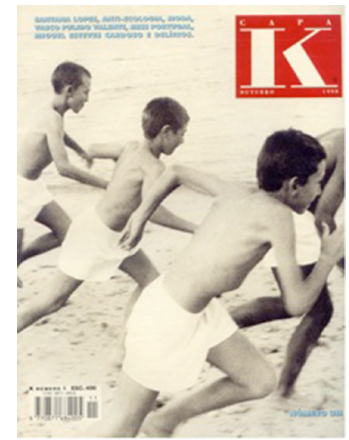

In October 1990 Miguel Esteves Cardoso founded Kapa magazine with some collaborators from $\mathrm{O}$ Independente. The magazine was an editorial extension of the newspaper cultural supplement: VIDAS, with small articles on mundane issues, interviews, chronicles, critical reviews on books, music, fine arts, fashion, cultural agenda and photography essays. Kapa was still under a conservative ideology, determined to propose a new national identity of Portugal in a European context. However, it was detached from the "old" conservative agents and took part of a new liberal expression: urban, provocative, libertarian, with strong sense of style.

Kapa graphic project belongs to João Botelho (filmmaker) and Luís Miguel Castro. It was printed in 4 colours offset in glossy paper, glue binding. It was a sophisticated visual object among his pairs; it used classical typography such as Bodoni and modern typography like Futura (types that were not so usual to find in printing industry by that time). It was produced through photomechanical process, composed with scissors, tape and glue, being the art direction supported by elegant photographic productions and illustrations from emerging young artists. 
According to Luís Miguel Castro, the strongest graphic reference in Kapa layout was Alexey Brodovitch's Harper's Bazaar (1934-1958). Brodovitch legacy to Kapa spreads is clear: the use of white space as an important composition element, the bleeding photos, the cinematic display of the images, the use of classical and modern typography, the elegance of a graphic composition where text and image interact.
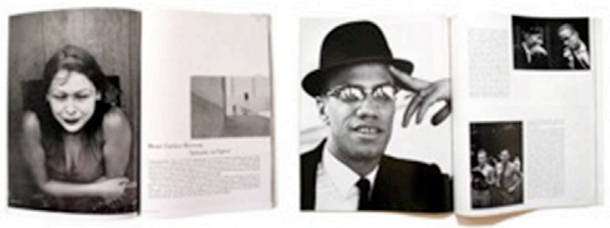

Figure 2.

On the left column: spreads of Harper's Bazaar; on the right column: spreads of Kapa magazine.
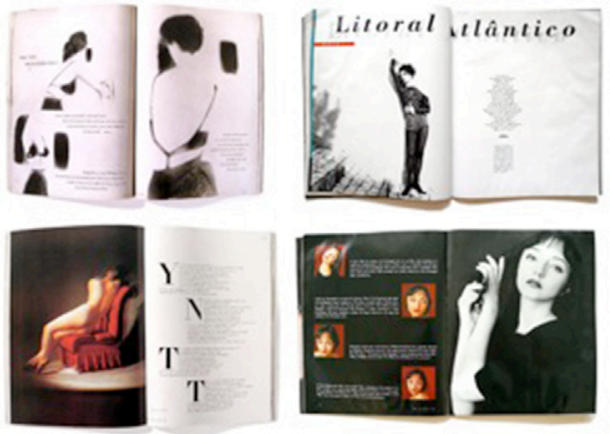

The period between wars was crucial for the dissemination of Modern graphic design by industry, press and advertising. Such association of modern vocabulary to consumption society promoted its consolidation in public imagination, allowing the acknowledgement of Modernism as an institutionalized movement, thus a graphic authority in design history.

\section{Post Modernism and historical references}

By the end of the 50 and the early 605 , a different approach towards the modern society arose: objects emerged in an increasing consumer society; means of production and distribution of goods were gradually more efficient; and worldwide; politics was being replaced by economics; communication and technology were developing as fast as ever.

After Hiroshima and Nagasaki nuclear bombing in 1945 the rationality of the Modern project was under critical scrutiny. Set up as a moment of crisis, some thinkers assume postmodernism as a self-conscious moment of Modernism itself. Closely engaged with late capitalism and neo-liberal policies, postmodernism was strongly attached to political affiliations. Hal Foster distinguishes two kinds of postmodernism: one of reaction and another of resistance. Both strands shared the critique to the Modernism project as a reduction to style (e.g. the "formalism" of International Style). The postmodernism of reaction was under the influence of a neo-conservative ideology and proposed a return to traditional values (in art, family, religion) in order to keep the political and economical status quo. In opposition, the postmodernism of resistance was against the cosmetic appeal of reactionary postmodernism and was "concerned with a critical deconstruction 
theme 2

memory

Figure 3 .

El Lissitzky. Beat the Whites with Red Wedge (1919) strand 1

design histories: tradition, transgression and transformations

of tradition, with a critique of origins, not a return to them. In short, it seeks to question rather than exploit cultural codes, to explore rather than conceal social and political affiliations." (Foster 1983: x)

Since the 7os graphic design was beyond a single style. In fact, it is characterized by several cultural tendencies, from punk to surf culture, techno, retro, vernacular... The assumption that there wasn't a single and unique vision of reality gave postmodern objects the task of questioning all communication process, becoming aware of their own meaning and significance. The neo-conservative strand in postmodern graphic design, which promoted a return to traditional values tended to reinforce the opposition towards the modernist establishment. The appropriation of anachronistic graphic references was set as a political strategy to promote an alternate relation towards modernity.

"Postmodernism played on historical associations as stylistic references, reconfiguring political meaning in process. Authenticity and originality were discounted" (Drucke and McVarish 2009: 301).

Design history was a subject to be used, appropriated and subverted by postmodern graphic objects. Those references were used as an iconographic source for designers, but instead of being sacred, there were used to build new speeches with different meanings, mostly related to critical implications. The notion of past as an ideological construction, made postmodern objects free to quote, question the design history itself. The appropriation of past design grammar was set as a free creative process in postmodern culture. The historical reference of Kapa magazine to Brodovitch art direction in Harper's Bazaar leads us to a question: is the appropriation of past references an exclusive practice of postmodern design?

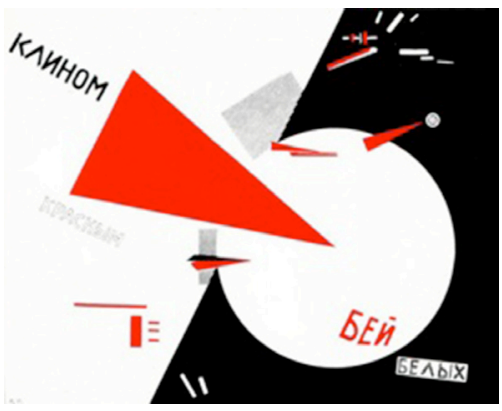

\section{The migration of Modernism}

The exile of European cultural agents since the World War I and World War II to USA is one of the most important events in American culture. This migration explains how cultural movements tend to adapt under new contexts, and how Modernism, especially Constructivism graphics were applied under a completely different ideological and political programme from their original ones.

Russian Constructivism had a strong filiation in Soviet Socialism. Artists, designers and architects had the social task to inform and educate the people, the working class. Art had an important role in spreading the socialism ideology: 
"The Constructivists rejected the idea of a unique work of art as belonging the old bourgeois society. Armed with the forms of the new abstract painting, they set out to demolish the division between art and labour" (Hollis 2001: 46).

As the perfect combination between art and technology, graphic design became a medium of the revolutionary program. By borrowing plastic language from avant-garde movements like Futurism, Dada, Suprematism, graphic design incorporated and spread the principles of a new industrial society, concerned with the labour and social conditions of the working class and against the bourgeois establishment:

"Painters, Architects, Sculptors, you whom the bourgeoisie pays with high rewards for your work - out of vanity, snobbery, and boredom - Hear! To this money there clings the sweat and blood and nervous energy of thousands of poor hounded human beings - Hear! It is an unclean profit... we must be true socialists - we must kindle the highest socialist virtue: the brotherhood of man" (Wolfe 1981: 12).

This "Novembergruppe" manifest (an expressionist German group which included Moholy-Magy who later taught in Bauhaus) defends the social mission that graphic design should express through geometric abstraction, formal reduction, dynamic asymmetry, high contrast black and white, boldly structured typographic arrangements, collage and photomontage as image composition.

The rise of fascist regimes in Europe (Germany, Italy, Spain) forced most of these artists and architects to migrate to USA, which had become a great world nation, wealthy and economically stronger than Europe. There was no royalty, or noblesse or even bourgeoisie. "Starting from zero", Bauhaus most famous principle on changing society seemed to have found place to blossom. The economic growth and technologic development lead this new nation into a consumption society and modernist designers and architects had to deal with a new paradigm: to produce according capitalism and market logics. Designers were asked to work in publicity, advertising, fashion, mainstream magazines and newspapers in order to make consumption glamorous and "to shape the notion of contemporary life of abundance in the popular imagination" (Drucker and McVarish 2009: 215). The Modernist graphic legacy was absorbed by consumption industry, letting its political and ideological features blur into stylish and aesthetic goals.

\section{3. "Astonish me!"}

Alexey Brodovitch played an important role in introducing many ideas and aesthetics of European Modernism in USA, as both art director and teacher. Born in Russia in 1898 in the middle of an aristocratic and wealthy family, politically sympathetic with czarist Russia, Brodovitch fought against the Bolsheviks and served with the White Army. Moving later to Paris, he started working in an advertising agency. In the beginning of the 30 s he moved to America to teach in Philadelphia College. The Harpers Bazaar editor Carmel Snow asked him to modernize the publication in 1934. This collaboration lasted 24 years. Brodovitch had the ability to apply the principles of modern graphic design to the magazine's layout. He borrowed El Lissitzky notion of "flow", where graphic layout was faced as a cinematic display, an analogy between the magazine spreads and film sequence in order to create a new visual experience. The white space was an important layout element, the photomontage and juxtaposition of photos were used to make images and text communicate to each other, adding visual meaning to editorial contents. The photos 
were cropped until the page bleed, giving the idea that the "story" continued beyond the layout, in contrast with the shy effect of the frame.

\section{Conclusion}

Brodovitch's work in Harper's Bazaar is an example of how avant-garde visual legacy was appropriated by a consumerism industry in order to promote consumption as an ideal, letting the original socialist values vanish into style and goods.

The "retro" expression in postmodern design was a systematic evidence of appropriation of design history. As John Savage outlined in "The Age of Plunder" (The Face magazine in 1983), the excessive use of past references in Pop culture was an "explicit device for the reinforcement and success of the New Right" (Savage 1983: 45). Savage alerts the appropriation of past is attached to an ideological strategy to support neoliberal politics:

"Savage took the view that this visual plunder was a symptom - one of many of a Thatcherite political culture in which everything is turned into a disposable consumer commodity" (Poynor 2003: 77).

Fully aware of the importance of style and looks and embedded in a nostalgic tendency towards the past (the Portuguese values and identity), Kapa magazine needed to convoke elegant and glamorous graphics to spread the fantasy. Reluctant about the Portuguese integration in UE, the magazine was determined to construct an alternate cultural identity towards the economic European domain. The use of modernism graphic language (borrowed by Brodovitch), made this construction more seductive to the public, allowing the magazine to be distinguished among its pairs. Kapa magazine was the editorial arm of an ideological opposition, led by a new right that was clever, humorous, fashionable and critical on how capital flow tended to shape global politics. Supported by "classical modernism" Kapa was nearly committed to the postmodernism of reaction, according to Hal Foster. Nevertheless it is a tacit example of how graphic design quotes its own history as a commodity, completely detached from its original background.

\section{References}

Adamson, G. and Pavitt, J. (ed) (2011) Postmodernism style and subversion, 1970-1990, London: V\&A Publishing.

Cardoso, M. E. (1988) "A aventura dos jornais", O Independente, May pp. 2. Drucker, J. and McVarish, E. (2009) Graphic Design History. A Critical Guide, New Jersey: Pearson Prentice Hall. Foster, H. (1983) Postmodern culture, 4nd edition, London: Pluto Press. Hollis, R. (2001) Graphic Design: A Concise History, London: Thames \& Hudson. Kalman T., Miller, J. A. and Jacobs, K. (2009) 'Good History / Bad History'. In Looking closer Critical writings on graphic design (pp. 25-33). New York: Allworth Communications Inc. Poynor, R. (2003) No more rules. Graphic Design and Postmodernism, New Haven: Yale University Press. Purcell, K. W. (2002) Alexey Brodovitch, London: Phaidon Press. Savage, J. (1983) 'The Age of Plunder', The Face, January, pp. 45-49. Wolfe, T. (1981) From Bauhaus to our house, New York: Picador. 
